\title{
MASLAHAH MURSALAH \\ IMPLEMENTASINYA PADA TRANSAKSI EKONOMI
}

\author{
Luqmanul Hakiem Ajuna \\ IAIN Sultan Amai Gorontalo
}

Email: luq.h.ajuna@iaingorontalo.ac.id

\begin{abstract}
Economic transactions in the financial services sector are increasing in latest years, this is indicated by the growing development of Islamic financial institutions in Indonesia supported by government policies regarding the sector. Later worries emerged as the financial sector was rapidly advancing, namely increasingly fierce competition between the managerial financial sectors in question which had an impact on the neglect of sharia values in the service products it sparked. There are many methods of ijtihad, beside Quranic and Sunnah method, that can be used as an alternative choice in maintaining sharia values in sharia financial sector products. For example the method of ijtihad maslahah mursalah which, although it is currently still debated among Muslim scholars and scholars, has an influence on the Islamic financial sector.
\end{abstract}

Keywords: marsalah mursalah, islamic financial institution, economic transactions.

\begin{abstract}
Abstrak
Transaksi ekonomi di sektor jasa keuangan dari tahun ketahun semakin meningkat, hal ini ditandai dengan semakin berkembangnya lembaga keuangan syariah di indonesia yang didukung oleh kebijakan-kebijakan pemerintah berkenaan dengan sektor tersebut. Belakangan kekhawatiran muncul seiring maju pesatnya sektor keuangan ini yaitu persaingan yang semakin ketat diantara manajerial sektor-sektor keuangan dimaksud yang berdampak pada diabaikannya nilai syariah dalam produk jasa yang dicetuskannya. Selain bersumber pada Alquran dan sunah, ada banyak lagi metode ijtihad yang dapat dijadikan alternatif pilihan dalam mempertahankan nilai-nilai syariah dalam produk sektor keuangan syariah. Misalnya metode ijtihad marsalah mursalah yang meski saat ini masih suka diperdebatkan diakalangan ulama dan cendekiawan muslim namun memberi pengaruh dalam sektor keuangan syariah.
\end{abstract}

Kata kunci: marsalah mursalah, lembaga keuangan syariah, transaksi ekonomi. 


\section{A. PENDAHULUAN}

Allah swt. secara keseluruhan menetapkan hukum kepada hambanya berupa perintah dan larangan. Keduanya mengandung maslahah, sehingga setiap manusia yang mengerjakan semua perintahnya maka akan mendapatkan manfaat baik secara langsung maupun tidak langsung. Selain itu semua larangan Allah hasurlah dijauhi oleh umat manusia karena akan mendatangkan mafsadah atau kerusakan baik untuk dirinya mapun orang lain.

Allah dalam menetapkan hukum ada yang secara nyata menagandung perintah dan larangan ada pula berupa perumpaan, selian itu pula ada yang perlu ditafsirkan oleh para ulama. Namun untuk masalah marsalah mursalah ini tidak ada dalil Alquran, sunah, ijma atau sumber hukum lain yang membenarkan atau menyalahkan suatu masalah yang sedang terjadi di lingkungan masyarakat. Sehingga sebagian ulama berpendapat bahwa jika kebiasaan itu mengandung maslahah maka boleh dilaksanakan. Berangkat dari kaidah fikih yang membolehkan segala bentuk transaksi kecuali jika ada nash yg melarang, maka eknomi menjadi legit umtuk dibahas. Oleh karena itu penulis melalui tulisan ini akan membahas apa dan bagaimana posisi marsalah mursalah dalam transaksi ekonomi.

\section{B. GAMBARAN UMUM MASALAH}

Hukum yang bersumber dari Alquran, sunah, ijma dan lainnya kesemuanya menyangkut kemaslahatan manusia. Begitu pula dengan dasar penentuan dalam marsalah mursalah untuk jelasnya akan digambarkan sebagai berikut:

1. Pengertian Maslahah

Maslahah berasal dari kata shalaha dengan penambahan "alif" di awalnya yang secara arti kata berarti "baik" lawan dari kata "buruk" atau 
"rusak". Ia adalah masdar dengan arti kata shalaah, yaitu "manfaat" atau "terlepas daripadanya kerusakan".

Pengertian maslahah dalam bahasa Arab berarti "perbuatanperbuatan yang mendorong kepada kebaikan manusia " dalam artinya yang umum adalah setiap segala sesuatu yang bermanfaat bagi manusia, baik dalam arti menarik atau menghasilkan seperti menghasilkan keuntungan atau kesenangan; atau dalam arti menolak atau menghindarkan seperti menolak kemudharratan atau kerusakan. Jadi setiap yang mengandung manfaat patut disebut maslahah, dengan begitu maslahah mengandung dua sisi, yaitu menarik atau mendatangkan kemaslahatan dan menolak atau menghindarkan kemudharatan. ${ }^{1}$ AlGhazali menjelaskan bahwa menurut asalnya maslahah itu berarti sesuatu yang mendatangkan manfaat (keuntungan) dan menjauhkan mudarat (kerusakan), namun hakikat dari maslahah adalah memelihara tujuan syara (dalam menetapkan hukum), sedangkan tujuan syara dalam menetapkan hukum itu ada lima, yatu: memelihara agama, jiwa, akal, keturunan, dan harta.

Dari beberapa definisi tentang masalahah yang dikemukakan oleh para ahli di atas, maka dapat ditarik simpulan bahwa maslahah adalah sesuatu yang menurut manusia baik dan sesuai dengan tujuan syara' untuk menentukan hukum karena mendatangkan kebaikan dan menghindarkan diri manusia dari keburukan.

${ }^{1}$ Amir Syarifudin, Usul Fikih, (Jakarta: Kencana, 2014), jilid 2, h. 367 - 169 
2. Jenis-Jenis Maslahah

Berangkat dari pengertian di atas marsalah mursalah maka dapat dibagi kedalam beberapa bentuk:

a. Dari keberadaan Maslahah menurut Syara'

1) Maslahah al-Mu'tabarah, yaitu kemaslahatan yang didukung oleh syara' maksudnya ada dalil khusus yang menjadi dasar bentuk dan jenis kemaslahatan tersebut. ${ }^{2}$ Maslahah ini dapat dijabarkan lagi kedalam dua bentuk munaasib mulaaim dan munaasib mu'atsir berikut penjelasannya: ${ }^{3}$

Pertama, munaasib mu'atsir yaitu ada petunjuk syara dalam bentuk nash atau ijma' yang menetapkan bahwa maslahah dijadikan alasan dalam menetapkan hukum. Contohnya tidak baiknya mendekati perepuan yang sedang haid dengan alasan haid itu adalah penyakit. Kedua munaasib mulaaim yaitu tidak ada petunjuk langsung dari syara' baik dalam bentuk nash atau ijma' terhadap perhatian syara' terhadap maslahah tersebut, namun secara tidak langsung ada. Contohnya berlanjutnya perwalian ayah terhadap anak gadisnya dengan alasan anak gadisnya itu "belum dewasa", bolehnya jama' shalat bagi yang mukim karena keadaan hujan tersebut memiliki hukum syara dalam ijma' karena disandarkan pada dalam keadaan perjalanan.

2) Maslahah Al-Mulghah yaitu kemaslahatan yang ditolak syara karena bertentangan dengan ketentuan syara. ${ }^{4}$ Contohnya seorang raja atau orang kaya yang mencampuri istrinya di siang hari pada bulan Ramadhan. Untuk orang ini sanksi yang

\footnotetext{
${ }^{2}$ Nasrun Harun, Ushul Fiqih, Cet. II (Jakarta: Logos Wacana Ilmu, 1997), h. 117.

${ }^{3}$ Amir Syarifudin, Usul Fikih, jilid 2,h. 373-374.

${ }^{4}$ Nasrun Harun, Ushul Fiqih, h. 117.
} 
paling baik adalah disuruh puasa dua bulan berturut-turut, karena cara inilah yang diperkirakan akan membuatnya jera membuat pelanggaran. Pertimbangan ini memang baik dan masuk akal bahkan sejalan dengan tujuan syari' dalam menetapkan hukum yaitu menjerakan orang dalam melakukan pelanggaran. Namun apa yang dianggap baik oleh akal ini, ternyata tidak demikian menurut syari', bahkan ia menetapkan hukum yang berbeda dengan itu, yaitu harus memerdekakan hamba sahaya, meskipun sanksi ini bagi orang kaya atau raja dinilai kurang relevan untuk dapat membuatnya jera.

Contoh lain umpamanya, dimasa kini masyarakat telah mengakui emansipasi wanita untuk menyamakan derajatnya dengan laki-laki. Oleh kerana itu mereka menyamakan perolehan dari pembagian harta warisan. Namun dalam islam dengan jelas telah memberi tata cara dalam pembagian harta warisan tersebut dengan jelas. ${ }^{5}$

3) Marsalah mursalah yaitu kemaslahatan yang keberadaannya tidak didukung syara' dan tidak pula dibatalkan/ditolak syara'melalui dalil-dalil yang rinci. ${ }^{6}$ Kemaslahatan dalam bentuk ini terbagi atas dua yaitu Maslahah al-ghariban dan Maslahah al-mursalah.

Maslahah al-ghariban, yaitu kemaslahatan yang asing atau kemaslahatan yang sama sekali tidak ada dukungan dari syara'. Sedangkan Maslahah al-mursalah, kemaslahatan yang tidak didukung oleh serkumpulan makna nash (ayat atau hadist).

${ }^{5}$ Amir Syarifudin, Usul Fikih, jilid 2,h. 375-376..

${ }^{6}$ Ibid. h. 376. 
b. Dari Kandungan Maslahah

1) Maslahah al-Ammah, yaitu kemaslahatan umum yang menyangkut kepentingan orang banyak. Kemaslahatan umum ini tidak berarti untuk semua kepentingan orang, tetapi bisa berbentuk kepentingan mayoritas ummat/kelompok. Misalnya ulama memperbolehkan membunuh penyebar bid'ah yang dapat merusak akidah umat, karena menyangkut kepentingan orang banyak.

2) Maslahah al-khasha, yakni kemaslahatan pribadi seperti kermaslahatan yang berkaitan dengan pemutusan hubungan perkawinan seseorang yang dinyatakan hilang (mafqud)

Pentingnya pembagian kedua kemaslahatan ini berkaitan dengan mana yang harus didahulukan apabila kemaslahatan umum bertentangan dengan kemaslahatan pribadi. Dalam pertentangan ke dua kemaslahatan ini, Islam mendahulukan kemaslahatan umum daripada kemaslahatan pribadi. ${ }^{7}$

c. Dari segi berubah atau tidaknya Maslahah

1) Maslahah al-Tsabitah, yakni kemaslahatan yang bersifat tetap, tidak berubah sampai akhir zaman. Misalnya kewajiban shalat, puasa, zakat, dan haji.

2) Maslahah al-Mutagayyirah, yakni kemaslahatan yang berubahubah sesuai dengan perubahan tempat, waktu, dan subjek hukum.

Pentingnya pembagian ini menurut Mustafa al-Syalabi, dimaksudkan untuk memberi batasan kemaslahatan mana yang bisa berubah dan tidak. ${ }^{8}$

${ }^{7}$ Ibid, h. 117.

${ }^{8}$ Nasrun Harun, Ushul Fiqih,h. 117. 


\section{MASLAHAH MURSALAH}

\section{Pengertian Mursalah}

Marsalah mursalah menurut lughat terdiri atas dua kata, yaitu maslahahdan mursalah. Kata mursalah berasal dari kata bahasa arab صََحَ -

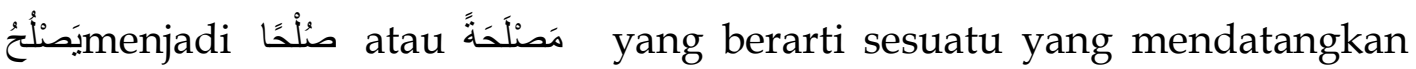
kebaikan, sedangkan kata maslahah berasal dari kata kerja yang

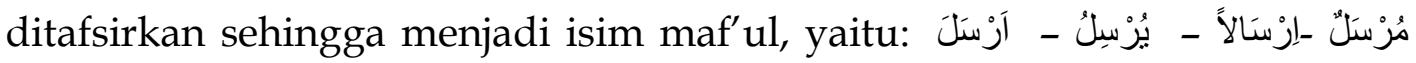
menjadi مُرْسَلْ yang berarti diutus, dikirim atau dipakai (dipergunakan). Perpaduan dua kata menjadi "Marsalah mursalah" yang berarti prinsip kemaslahatan (kebaikan) yang dipergunakan menetapkan suatu hukum Islam, juga dapat berarti suatu perbuatan yang mengandung nilai baik (manfaat) ${ }^{9}$

Penjelasan definisi ini yaitu bahwa pembentukan hukum itu tidak dimaksudkan, kecuali merealisir kemaslahatan ummat manusia. Artinya mendatangkan keuntungan bagi mereka dan menolak madharat serta menghilangkan kesulitan daripadanya. Dan bahwasanya kemaslahatan ummat manusia itu tidak terungkap bagian-bagiannya, tidak terhingga pula individu-individunya. Maslahah itu juga baru menurut barunya keadaan ummat manusia dan berkembang menurut perkembangan lingkungan. Sedangkan pembentukan hukum itu, terkadang mendatangkan keuntungan pada suatu zaman, hukum itu terkadang mendatangkan keuntungan bagi suatu lingkungan dan bisa mendatangkan madharat bagi lingkungan yang lain. ${ }^{10}$

Ada beberapa rumusan definisi yang berbeda tentang marsalah mursalah ini, namun masing-masing memiliki kesamaan dan pendekatan pengertiannya. Diantara devinisi tersebut diantaranya Al-Ghazali dalam

${ }^{9}$ Khairu Umam, at, al; Ushul Fiqih I, Cet. I ,(Bandung: CV. Pustaka Setia, 1998), h. 135.

${ }^{10}$ Abd. Wahab Khallaf, Kaidah-Kaidah Hukum Islam, (Ushul Fiqih), diterjemahkan oleh Nur Iskandar Al-Barsany, (Jakarta: Rajawali, 1996), h. 126. 
kitab al-Mustasyfa merumuskan masalahah adalah apa-apa (maslhahah) yang tidak ada bukti baginya dari syara' dalam bentuk nash tertentu yang membatalkannya dan tidak ada yang memperhatikannya. Sementara AlSyaukani dalam kitabnya Irsyaad al-Fuhul memberikan definisi masalahah yang tidak diketahui apakah syari' menolaknya atau memperhitungkannya. Disisi lain Ibnu Qudamah dari ulama Hambali merumuskan maslahah yang tidak ada bukti petunjuk tertentu tertentu yang membatalkannya dan tidak pula yang memerhatikannya. ${ }^{11}$

Dari pengertian yang diungakapan di atas, maka dapat ditarik simpulan bahwa marsalah mursalah adalah menarik hukum terhadap sesuatu masalah yang tidak dibahas dalam nash namun memiliki dampak maslahah bagi umat manusia. Yaitu mendatangkan kebaikan dan menolak kerusakan.

\section{Tingkatan-tingkatan Marsalah mursalah}

Dari keseluruhan jenis-jenis maslahah yang telah diuraikan di atas akan mampu dirangkum dalam tingkatan-tingkatan masalahah. Yaitu maslahah dharuriyyah, maslahah hajiyyat, dan maslahah tahsiniah. Maslahah dalam pengertian syara' tidak hanya memikirkan baik dan buruk sesuatu, dan bukan pula mengmabil kenikmatan dan menjauhi kerusakan. namun jauh lebih dari itu dalam menetapkan hukum yaitu harus memelihara blima prinsip pokok kehidupan.

Sebagai tokoh yang paling popular membahas masalah ini Abu Ishaq al-Shatibi berhasil merumuskan lima tujuan hukum Islam, yakni: hifdz addin (memelihara agama), hifdz an-nafs (memelihara jiwa), hifdz al'aql (memelihara akal), hifdz an-nasb (memelihara keturunan), dan hifdz al-maal (memelihara harta). ${ }^{12}$ Sementara Hamka Haq dalam bukunya "Falsafat Ushul Fiqih" mengemukakan bahwa terdapat 6 aspek kemaslahatan yang

\footnotetext{
${ }^{11}$ Amir Syarifudin, Usul Fikih, jilid 2, h. 378.

${ }^{12}$ Ibnu Mandzur, Lisaan Al- 'Arab Jilid I, (Kairo: Darul Ma’arif, tt), h. 3642.
} 
menjadi tujuan syariat diantaranya, (1) memelihara agama, (2) memelihara jamaah, (3) memelihara jiwa, (4) memelihara akal, (5) memelihara keturunan dan (6) memelihara harta benda. Aspek ini diurut berdasarkan prioritas urgensinya. ${ }^{13}$ Mengenai kemaslahatan setiap aspek dari lima prinsip tersebut akan diurutkan sesuai dengan kepentingannya sebagai berikut:

a. Maslahah dharuriyyah adalah kemaslahatan yang keberadaannya sangat dibutuhkan oleh kehidupan manusia. Artinya, kehidupan manusia tidak punya arti apa-apa bila satu saja dan prinsip yang lima itu tidak ada. ${ }^{14}$ Secara bahasa berarti kebutuhan yang mendesak atau darurat. Dalam hal mu'amalat, Syathibi mencontohkan harus adanya 'iwadh tertentu dalam transaksi perpindahan kepemilikan, jual-beli misalnya. Dalam kategori ini ada lima hal yang perlu diperhatikan, yaitu memelihara agama, memelihara jiwa, memelihara akal pikiran, memelihara kehormatan dan keturunanan, serta memelihara harta benda. ${ }^{15}$ Dalam hal ini Allah swt. melarang murtad untuk memelihara agama, melarang membunuh untuk memelihara jiwa, melarang minum minuman keras untuk memelihara akal, melarang berzina untuk memelihara kturunan, dan melarang mencuri untuk memelihara harta. ${ }^{16}$

Sehingganya dapat dikatakan semua yang secara langsung terpeliharanya kelima prinsip tersebut adalah maslahah. Karena jika salah satu diantaranya tidak terpenuhi akan menyebabkan kerusakan bahkan kematian. Allah swt. sesungguhnya sangat

\footnotetext{
${ }^{13}$ Hamka Haq, Falsafat Ushul Fiqih (Ujung Pandang:Yayasan Al-Ahkam, 1998), h. 76.

${ }^{14}$ Amir Syarifudin, Usul Fikih, jilid 2,h. 371.

15 Muhammad Khalid Mas'ud, Filsafat Hukum Islam dan Perubahan Sosial, terjemahan oleh Yudian W. Asmin, (Surabaya: Al Ikhlas, 1995), h. 225.

${ }^{16}$ Amir Syarifudin, Usul Fikih, jilid 2, h. 371.
} 
mencintai kebaikan dan membenci keburukan. Dalam pelaksanaannya, kelima prinsip itu harus diutaman sesuai dengan urutannya.

b. Maslahah hajiyyah adalah kemaslahatan yang tingkat kebutuhan hidup manusia keberadaannya tidak berada pada dhariri. Bentuk kemaslahatannya tidak secara langsung bagi pemenuhan kebutuhan pokok yang lima tadi. Tetapi secara tidak langsung menuju kearah sana seperti dalam hal memberi kemudahan bagi pemenuyan kehidupan manusia. ${ }^{17}$ Secara bahasa berarti kebutuhan-kebutuhan sekunder. Apabila kebutuhan ini tidak terwujud tidak sampai mengancam keselamatan, namun akan mengalami kesulitan. Untuk menghilangkan kesulitan tersebut, dalam Islam terdapat hukum rukhsa (keringanan) yaitu hukum yang dibutuhkan untuk meringankan beban, sehingga hukum dapat dilaksanakan tanpa rasa tertekan dan terkekang. ${ }^{18}$ Contohnya menuntut ilmu agama untuk tegaknya agama, makan untuk menjaga kelangsungan hidup, mengasah otak untuk kesempurnaan akal, melakukan jual beli untuk mendapatkan harta. ${ }^{19}$

Jika tujuan syara' untuk menjaga kemaslahatan yang lima tersebut tidak dipenuhi tidak secara langsung dapat mengakibatkan kerusakan, namun lambat laun manusia akan merasakan kerusakan atas ketidak dipenuhinya maslahah hajiyyat ini.

c. Masalahah tahsiniyah maslahah yang kebutuhan hidup manusia kepadanya tidak sampai tingkat dharuri, juga tidak sampai tingkat

${ }^{17} \mathrm{Ibid}$, h. 372.

${ }^{18}$ Khalid Mas'ud, Filsafat Hukum Islam dan Perubahan Sosial, h. 225.

${ }^{19}$ Amir Syarifudin, Usul Fikih, jilid 2, h. 372. 
haajiyat. Namun kebutuhan tersebut perlu dipenuhi dalam rangka memberi kesempurnaan dan keindahan bagi kehidupan manusia. Masalhah dalam bentuk tahsini tersebut, juga berhubungan dengan lima kebutuhan pokok manusia. ${ }^{20}$ Secara bahasa berarti hal-hal penyempurna. Tingkat kebutuhan ini berupa kebutuhan pelengkap. Apabila kebutuhan ini tidak terpenuhi, maka tidak akan mengancam dan tidak pula menimbulkan kesulitan. ${ }^{21}$

Dari penjelasan beberapa tingkatan kebutuhan manusia tersebut maka dapat ditarik simpulan bahwa jika lima prinsip tersebut dipenuhi akan menimbulkan kemaslahatan yang luar biasa. Namun jika tidak dipenuhi juga tidak akan menimbulkan kerusakan.

Ketiga tingkatan marsalah mursalah diatas harus diprioritaskan sesuai dengan urutannya. Karena urutannya menandakan kepentingan pemenuhan kehidupan manusia. Pemenuhan pertama adalah pada maslahah daharuriyyah, kemudian disusul oleh maslahah hajiyyat, dan untuk melekapi tingkat kemaslahatan adalah dengan memenuhi kebutuhan maslahah tahsiniah. Apabila terjadi benturan kepentingan diantara ketiga tingkatan tersebut, maka harus kembali kepada tingkatan awal dan kemudian secara berurut.

Selain itu, wajib pula mengurutkan pemeliharaan lima prinsip masalahah yang dimuali darimemelihara agama, memelihara jiwa, memelihara akal, memelihara keturunan, dan memelihara harta. Jika terjadi benturan, maka prioritas adalah prinsip yang berada di urutan teratas dalama menyelesaikan masalah tersebut. Misalnya jihad dijalan Allah swt. disini disyariatkan menegakkan agama meskipun dengan

\footnotetext{
${ }^{20}$ Ibid, h. 372.

21 Nasrun Rusli, Konsep Ijtihad Al Syaukani: Relevansinya bagi Pembaruan Hukum Islam di Indonesia, (Jakarta: Logos, 1999), h. 43.
} 
mengorbankan jiwa dan harta. sebagaimana firman Allah dalam surat AlMaidah ayat 4 .

Ayat di atas menunjukan keharusan mendahulukan agama atas jiwa dan harta. Begitu pula syariat membolehkan meminum minuman khamar karena dalam keadaan tercekik karena untuk melepaskan keadaan daruratnya. Hal ini menunjukan bahwa memelihara jiwa itu harus didahulukan daripada memelihara akal.

\section{MARSALAH MURSALAH SEBAGAI METODE IJTIHAD}

Seperti yang telah dijelaskan sebelumnya bahwa maslahah jika dilihat dari keberadaan maslahah menurut syara' terdiri dari tiga bentuk. Yaitu maslahahal-Mu'tabarah, maslahah al-mulgghah, dan marsalah mursalah.

Jumhur ulama sepakat dalam penggunaan maslahah al-Mu'tabarah, namun tidak menempatkannya sebagai dalil dan metode yang berdiri sendiri. Ia digunakan karena adanya petunjuk syara' yang mengakuinya baik secara langsung maupun tidak langsung. Pengakuan akan maslahah dalam bentuk ini sebagai bentuk ijtihad karena adanya petunjuk syara'. ia diamalkan dalam rangka mengamalkan qias.

Demikian pula terdapat kesepakatan ulama untuk tidak menggunakan maslahah al-Mulghah dalam berijtihad, karena walau ada maslahah-nya menurut akal dan dianggap sejalan dengan tujuan syara', namun bertentangan dengan dalil yang ada. Menurut jumhur ulama jika terjadi perbedaan antara nash danmaslahahmaka nash yang harus diutamakan. Tetapi murut Al-Thufi yang dinukilkan dari Al-Khallaf berpendapat bahwa apabila nash dan ijma' sejalan dengan pertimbangan menjaga maslahah, maka maslahah tersebut apat diamalkan karena dalam hal ini ada tiga unsur yang mendukungnya untuk dijadikan ketetapan hukum yakni nash, ijma', dan maslahah. Namun jika nash dan ijma' menyalahi pertimbangan maslahah maka yang didahulukan adalah 
pertimbangan maslahah. Tentunya nash yang dimaksud di sini adalah nash yang lemah dari segi wurud, dilaalah-nya. Demikian pula yang dimaksud dengan ijma' di sini adalah ijma' yang lemah.

Adanya perbedaan pendapat dikalangan ulama mengenai penggunaan maslahah sebagi metode ijtihad adalah karena tidak adanya dalil khusus yang menyatakan diterimanya maslahah itu oleh syari' baik secara langsung maupun tidak langsung, karena sebagaimana disebutkan di atas bahwa diamalkannya maslahah itu oleh jumhur ulama karena adanya dukungan syar'i, meskipun secara tidak langsung. Digunakannya maslahah itu bukan karena semata-mata ia adalah maslahah, tetapi karena adanya dalil syara' yang mendukungnya.

Opini yang menyebabkan perbedaan pendapat dalam penggunaan masalahah mursalah itu disebabkan oleh perbedaan ulama dan penulis usul fikih dalah menukilkan pendapat imam mazhab. Ada yang menukilkan Imam Malik sebagai pelopor marsalah mursalah yang kemudian diikuti oleh para pengikutnya, sehingga menjadi pendapat umum bahwa masalahah mursalah itu adalah dalilnya mazhab maliki. ${ }^{22}$ Mazhab Maliki yang merupakan pembawa bendera Maslahat Mursalah mengemukakan, setidaknya terdapat tiga alasan mengapa mashlahah mursalah tersebut dijadikan sebagai hujjah dalam penentuan hukum, yaitu sebagai berikut: ${ }^{23}$

1. Praktek para sahabat yang telah menggunakan maslahat mursalah diantarannya: - Sahabat mengumpulkan Al-Qur'an kedalam beberapa mushaf dengan alasan menjaga Al-Qur'an dari kepunahan atau kehilangan kemutawatirannya. - Khulafa ar-Rosyidun menetapkan keharusan menanggung ganti rugi kepada para tukang. Padahal menurut hukum asal kekuasaan mereka didasarkan atas kepercayaan (amanah). Jika tidak dibebani ganti rugi ia akan ceroboh dan tidak

${ }^{22}$ Amir Syarifudin, Usul Fikih, jilid 2, h. 3379-380.

${ }^{23}$ Muhammad Abu Zahrah, Ushul al-Fiqh (t.t.p: Dar al-Fikr Al-Islamiy), h. 280. 
memenuhi kewajibannya. - Umar Bin Khattab memerintahkan para penguasa (pegawai negeri) agar memisahkan antara harta kekayaan pribadi dengan harta yang diperoleh dari kekuasaannya - Umar Bin Khattab sengaja menumpahkan susu yang dicampur air guna member pelajaran kepada mereka yang mencampur susu dengan air - Para sahabat menetapkan hukuman mati kepada semua anggota kelompok (jama'ah) karena membunuh satu orang secara bersama-sama.

2. Adanya maslahat sesuai dengan maqosid as-Syar'i (tujuan-tujuan syar'i) artinya dengan mengambil maslahat berarti sama dengan merealisasikan maqosid as-syar'i

3. Seandainya maslahat tidak diambil pada setiap kasus yang jelas mengandung maslahah selama berada dalam konteks maslahat syar'iyyah, maka orang-orang mukallaf akan mengalami kesulitan dan kesempitan.

Namun Ibnu Al-Hajib dalam kitabnya al-Muntaha sebagai ulama senior mazhab Maliki meluruskan bahwa menghubungkan pendapat ini pada Imam Malik adalah tidak benar bahkan ia menukilkan pendapat kebanyakan ulama Maliki bahwa masalahah mursalah tidak punya dasar yang kuat sehingga harus ditolak. Yang dimaksud dengan dasar yang kuat itu adalah adanya $i^{\prime}$ tibar syar'i untuk dapat diterima sesuatu yang bernama marsalah mursalah. Inilah pendapat umum yang dipakai oleh jumhur ulama.

Tentang pandangan ulama Hanafi terhadap marsalah mursalah ini terdapat penukilan yang berbeda. Menurut Al-Amidi, banyak ulama yang beranggapan bahwa ulama Hanafi tidak mengamalkannya. Namun menurut Ibnu Qudamah, sebagian ulama Hanafi menggunakan marsalah mursalah. Tampaknya ulama yang berpendapat sebagian ulama Hanafi mengamalkan marsalah mursalah lebih tepat, karena kedekatan istihsan yang popular di kalangan Hanafi. 
Ulama Syafi'iyyah tidak menggunakan marsalah mursalah ini dalam berijtihad. Pendapat ini didukung oleh Al-Amidi dan Ibn-Hajib dalam kitabnya al-Muntaha. Imam Syafi'i tidak menyinggung masalah ini dalam kitab standarnya al-Risalah. Ibnu Subki sebagai pengikut Syafi'I tidak membahas masalah marsalah mursalah dalam pembahasan tersendiri, tetapi hanya menyinggungnya dalam bahasan tentang persyaratan al-'illah, dia sendiri menggunakan istilah al-munaasib sebagai pengganti istilah marsalah mursalah.

Namun ada pula ulama yang beranggapan bahwa maslahah murasalah ini berlaku di kalangan Syafi'i. Al-Syatibi dari kalangan Maliki menukilkan tentang digunakannya metode ini oleh ulama Syafi'i. bahkan Al-Gahazali sebagai pengikut Syafi'i menukilkan satu versi pendapat yang mengatakan bahwa Imam Syafi'i yang menggunakan marsalah mursalah tersebut. Ibnu Qudamah dari ulama Hambali juga menukilkan digunakannya marsalah mursalah oleh sebagian ulama Syafi'i.

Ulama yang menukilkan digunakannya marsalah mursalah dikalangan ulama Hanafiyah dan Syafi'iyyah berpendapat bahwa penggunaan itu tidak secara mutlak, tetapi dengan satu catatan bahwa meskipun masalahah ini tidak didukung oleh syara' secara langsung atau tidak, namun setidaknya maslahah itu dekat dengan prinsip pokok hukum syara' yang sudah ditetapkan.

Al-Gazali sebagai pengikut mzhab Syafi'I secara tegas dalam dua kitabnya (al-Madkuul dan al-Mushtasfa) menyatakan bahwa ia menerima penggunaan marsalah mursalah dengan syarat bahwa marsalah mursalah itu bersifat dharuri (menyangkut kebutuhan pokok dalam hidup), Qath'i (pasti) dan kulli (menyeluruh) secara kumulatif, Ibnu Subki dan al-Razi membenarkan pendapat Al-Ghazali seperti itu. Pendapt sahih yang mewakili pandangan ulama Hanbali menyatakan bahwa marsalah mursalah 
itu tidak memiliki kekuatan hujah dan tidak boleh melakukan ijtihad dengan menggunakan metode ini.

Kalangan ulama yang menolak penggunaan qiyas seperti al-Zhariri, ulama syiah dan sebagian ulama kalam mu'tazilah, begitu pula Qadhi alBaidhawi menolak penggunaan marsalah mursalah dalam berijtihad.

Dari uraian di atas dapat disimpulkan bahwa sikap ulama dalam penggunaan marsalah mursalah dalam berijtihad terbagi dalam dua kelompok. Pertama kelompok yang menolak penggunaan marsalah mursalah, yang oleh Al-Amidi digolongkan kepada mayoritas (jumhur) ulama, kedua kelompok yang menerima kemungkinan melakukan ijtihad dengan menggunakan marsalah mursalah.

Kalau diperhatikan perbedaan pendapat mazhab dalam mengamalkan marsalah mursalah itu sejatinya disebabkan oleh beda pemahaman tentang hakikat dari pengertian i'itibar yang menjadi syarat penerimaan maslahat itu. Ulama sepakat bahwa bila maslahat itu sudah ada padanya i'itibar syar'iy maka maslahat itu dapat diterima berdaya hujjah dan dapat dijadikan dalil dalam berijtihad. Namun i'tibar syar'iy itu ada dua bentuknya yaitu i'itibar secara langsung yang disebut juga al$M u^{\prime}$ tstsir dan i'itibar tidak secara langsung yang dinamakan al-Mualai. Ulama yang diperkirakan mengamalakan marsalah mursalah itu, seperti ulama Malikiyyah, diolak ulama lain karena adanya anggapan maslahat digunakannya tidak ada i'itibar sya'ir-nya, golongan ini akan membela dirinya dengan mengatakan bahwa maslahat yang digunakannya itu ada i'itibar syar'iy-nya, walaupun hanya dalam bentuk tidak langsung atau dalam bentuk mualaim. Sedangkan ulama Syafi'iyyah yang dituding juga mengmalkan marsalah mursalah itu akan menjawab bahwa mereka menga malkan marsalah mursalah karena padanya ada i'tibar-nya walaupun dalam 
bentuk tidak langsung atau mualaim. Dengan demikian, melihat perbedaan ini tidak mungkin hanya secara hitam putih. ${ }^{24}$

Kelompok yang menggunakan marsalah mursalah ini tidaklah menggunakannya tanpa syarat dengan arti harus terpenuhi padanya beberapa syarat. Yang merupakan syarat umum adalah marsalah mursalah itu hanya digunakan pada saat ditemukan nash sebagai bahan rujukan. syarat khusu untuk menjadikan marsalah mursalah sebagai ijtihad adalah:25

1. marsalah mursalah itu adalah maslahah yang hakiki dan bersifat umum, dalam arti dapat diterima olejh akal sehat bahwa ia betul-betul mendatangkan manfaat bagi manusia dan menghindarkan mudarat dari manusia secara utuh.

2. Yang dinilai akal sehat sebagai suatu maslahah yang hakiki betulbetul telah sejalan dengan maksud dan tujuan syara' dalam menetapkan setiap hukum, yaitu mewujudkan kemaslahatan bagi umat manusia.

3. Yang diliai akal sehat sebagai suatu maslahah yang hakiki dan telah sejalan dengan tujuan syara' dalam menetapkan hukum itu tidak berbenturan dengan dalil syara' yang telah ada baik dalam bentuk nash Alquran, Sunah maupun Ijma' ulama terdahulu.

4. marsalah mursalah itu diamalkan dalam kondisi yang memerlukan, yang seandainya masalahnya tidak diselesaikan dengan cara ini maka umat akan berada dalam kesempitan hidup, dengan arti harus ditempuh untuk menghindarkan umat dari kesulitan.

Dalam menguatkan pendapat mereka yang bersifat rasional tersebut baik yang setuju maupun tidak mengenai marsalah mursalah untuk dijadikan ijtihad. Kedua belah pihak sangat berhati-hati karena memang

${ }^{24}$ Amir Syarifudin, Usul Fikih, jilid 2, h. 380-382.

${ }^{25}$ Ibid, h. 383. 
pada dasarnya tidak ada nash yang mendukung maupun menolak diamalkannya marsalah mursalah ini.

Berikut argumen kalangan ulama yang menggunakan marsalah mursalah sebagai ijtihad:26

1. adanya takriir (pengakuan) Nabi atas penjelasn mu'adz Ibn Jabal yang akan menggunakan ijtihad al-ra'yi bila tidak menemukan ayat Alquran dan Sunah Nabi untuk menyelsaikan sebuah kasus hukum. Nabi sendiri waktu itu tidak membebaninya untuk mencari dukungan nash.

2. Adanya amaliah dan praktik yang begitu meluas dikalangan sahabat Nabi tentang penggunaan marsalah mursalah sebagai satu keadaan yang sudah diterima bersama oleh para sahabat tanpa saling menyalahkan. Contohnya pemilihan Abu Bakar sebagai khalifah yang dilakukan oleh para sahabat Nabi, pembentukan dewan pencetak uang pada masa Umar Ibn Khatab, penyatuan tata car abaca Alquran (kiraat) pada masa Utsman dan lainnya. Bahkan banyak terlihat maslahahyang digunakan sahabat Nabi berbenturan dengan dalil nash yang ada, seperti memerangi orang yang tidak mau membayar zakat pada waktu Abu Bakar, keputusan tidak memberikan hak zakat untuk mukallaf pada masa Umar, dan diberlakukannya adzan dua kali pada waktu Utsman Ibn Affan.

3. Suatu maslahah yang bila telah nyata kemaslahatannya dan telah sejalan dengan maksud pembuat hukum (syar'), maka menggunakan maslahah tersebut berarti telah memenuhi tujuan syar'i, meskipun tidak ada dalik khusus yang mendukungnya. Sebaliknya bila tidak digunakan untuk menetapkan suatu kemaslahatan dalam kebijakan hukum akan berarti melakukan tujuan yang dimaksud oleh syari' adalah suatu perbuatan yang batal. Karena itu dlam menggunakan maslahah itu

${ }^{26}$ Ibid, h. 384 . 
sendiri tidak keluar dari prinsip-prinsip syara', bahkan telah sejalan dengan prinsip-prinsip syara'.

Bila dalam keadaan tertentu untuk menetapkan hukum tidak boleh menggunakan metode marsalah mursalah, maka akan menempatkan umat dalam kesulitan. Padahal Allah swt. sendiri menghendaki kemudahan untuk hamba-Nya dan menjauhkan kesulitan. ${ }^{27}$

Kelompok ulama yang menolak marsalah mursalah sebagai metode ijtihad mengemukakan argumentasi yang diantaranya adalah: ${ }^{28}$

1. Bila suatu maslahah ada petunjuk syar'i yang membenarkannya atau disebut mu'tabarah, maka ia telah termasuk dalam umumnya qias. Seandainya tidak ada petunjuk syara' yang membenarkannya, maka ia tidak mungkin disebut sebagai suatu maslahah. Mengamalkan sesuatu yang diluar petunjuk syara' berarti mengakui akan kurangnya Alquran dan Sunah Nabi. Hal ini juga berarti tidak mengakui kesempurnaan risalah Nabi. Padahal Alquran dan Sunah Nabi menyatakan bahwa Alquran dan Sunah itu telah sempurna meliputi semua hal.

2. Beramal dengan maslahah yang tidak mendapatkan pengakuan sendiri dari nash akan membawa pada pengalaman hukum yang berlandaskan pada sekehendak hati dan menurut hawa nafsu. Cara seperti ini tidakhlah lazim dalam prinsip-prinsip Islami.

3. Menggunakan maslahah dalam ijtihad tanpa berpegang pada nash akan mengakibatkan munculnya sikap bebas dalam menetapkan hukum yang dapat mengakibatkan seorang teraniaya atas nama hukum. Hal yang demikian akan menyalahi prinsip penetapan hukum dalam Islam, yaitu "tidak boleh merusak, juga tidak ada yang dirusak.

${ }^{27}$ Q.S. al-Bakarah ayat 185.

${ }^{28}$ Ibid, h. 385. 
4. Seandainya dibolehkan berijtihad dengan metode maslahah yang tidak mendapat dukungan dari nash, maka akan memberi kemungkinan untuk berubahnya hukum syara' karena alasan berubahnya waktu dan berlainannya tempat berlakunya hukum isyara', juga karena berlainan antara seorang dengan orang lain. Dalam keaadan demikian, tidak akan ada kepastian hukum. Hal ini tidak sejalan dengan prinsip hukum isyara' yang universal dan lestasi sserta serta meliputi semua umat manusia.

\section{E. CONTOH MASLAHAH DALAM EKONOMI ISLAM}

Imam Al-Gazali dari amzhab Syafi'i berkata bahwa para sahabat nabi adalah contoh bagi umat di dalam pengambilan terhadap qiyas. Dan bisa dilihat dangan sejelas-jelasnya bahwa ketika memutuskan suatu hukum, mereka banyak bersandar kepada kemaslahatan. Perkataan Al-Ghazali ini juga dikemukakan oleh Imam Harmain di dalam pembebasan tentang alistidlaal yang tertera dalam kitab al-Burhaan.

Setelah seorang khalifah yang sangat terkenal telah mengadopsi almaslahah aialah Umar Ibn Al-Khattab, yang juga salah seorang sahabat Nabi. Dan, yang terpenting adalah hubungan antara al-mashlahah dan maqaashid syari'ah. Karena telah kita bahas sebelumnya bahwa inti dari maqaashid syari'ah yaitu yaitu menjaga kemaslahatan dan menghidari kerusakan. Di sini bisa digaris bawahi bahwa semua ijtihad fikih haruslah melihat kepada konteks istishlah (yang paling mendatangkan kemaslahatan). Dan seyogyanya pemahaman terhadap teks dan pengambilan hukum berdasarkan atas kaidah jail al-mashlahi wa daru almafaasid. Begitu juga dengan qias, haruslah menjaga kaidah di atas. Inilah arti mashlahah menurut mazhab Maliki. ${ }^{29}$

29 Fauzia dan Riyadi, Prinsip Dasar Ekonomi Islam. Prespektif Maqashid Syariah (Jakarta: Kencana, 2014), h. 57-58. 
Sebagai contoh, telah kita ketahui Nabi memberikan beberapa persyaratan pada praktik jual beli sehingga jual beli tersebut jauh dari unsur jahaalah (ketidak jelasan transaksi, kontrak, komoditas, harga, dan unsur lainnya) gharar, ghaban, mukhatharah (yang membahayakan) dan yang lainnya. Larangan jual beli karena unsur-unsur di atas dangat jelas sekali dan semua larangan di atas ada sebabnya. Yaitu untuk menjauhi kerusakan dan bertujuan untuk kemaslahatan. Akan tetapi ada beberapa kasus jual beli yang menyusahkan penjual dan pembeli jika harus memenuhi syaratsyarat di atas. Jadi, kemaslahatan penjual dan pembeli yaitu ketika hilangnya salah satu syarat di atas dan di sini ada dua pilihan.

1. Menjaga semua syarat jual beli apa adanya, akan tetapi membawa kesusahan.

2. Menjaga kemaslahatan dengan mempermudah syarat-syarat jual beli yang ada.

Maka mazhab Maliki lebih condong pada pilihan kedua. Contohnya adalah membolehkan jual beli kacang tanah dan sejenisnya yang masih di dalam kulit. Ketika jual beli kacang harus tanpa kulitnya karena alasan gharaar, maka akan memberatkan penjual dan pembeli. Dan ini bertolak belakang dengan esensi dari syariah itu sendiri, yaitu untuk menegakkan kemaslahatan di antara umat manusia.

Tidak diragukan lagi bahwa contoh di atas telah dilakukan oleh umat muslim sejak masa Nabi. Dan ini bukanlah gharar, karena menyangkut kemaslahatan manusia. Contoh di atas gaharar yasiir (sedikit). Dan ini tidak termasuk hal yang dilarang Allah swt. karena Allah swt. tidak melarang sesuatu yang membawa kepada kemaslahatan. Karena menurut Maliki bahwa dasar-dasar jual beli seperti yang termuat dalah Alquran surat AlBakarah ayat 88 dan 275 .

Contoh lainnya Maliki membolehkan jual beli yang tidak ada barangnya, akan tetapi disebutkan ciri-cirinya (mungkin zaman sekarang 
boleh menggunakan gambar). Jual beli bisa disahkan ketika barang sudah ada dan sesuai dengan ciri-cirinya. Adapun Syafi'i tidak membolehkan jual beli seperti ini. Sedangkan Hanafi membolehkan, akan tetapi harus ada pilihan barang dengan melihat barang tersebut (khiyar ru'yah), walaupun barang cocok dengan ciri-cirinya.

Ketika terjadi perang melawan nabi-nabi palsu pada zaman khalifah Abu Bakar, seiring dengan banyaknya para huffazh al-Qur'an wafat Abu Bakar mulai mengumpulkan berkas-berkas yang tercecer menjadi suatu tulisan al-Qur'an atas usulan dan desakan sahabat Umar bin Khattab. Beliau juga memerangi orang-orang yang tidak mau membayar zakat. Bahkan, menjelang ajal menghampiri beliaupun sempat berwasiat agar beliau digantikan oleh sahabat Umar bin Khattab sebagai khalifah.

Contoh lain dari penerapan marsalah mursalah ini ialah Umar menetapkan jatuhnya talaq tiga dengan sekali ucapan, menetapkan kewajiban pajak, menyusun administrasi, membuat penjara. Bahkan, Umar menghentikan hukuman potong tangan terhadap pencuri. Hal itu terjadi ketika di Madinah dirundung musim paceklik yang menyebabkan terjadinya krisis pangan.

Dengan demikian, semua bentuk kemaslahatan tersebut menjadi tujuan diundangkannya hukum-hukum sebagai kemaslahatan umum. Hal ini bisa dilakukan selama tidak ada dalil syara' yang menolaknya. 


\section{DAFTAR PUSTAKA}

Fauziya dan Riyadi, Prinsip Dasar Ekonomi Islam Perspektif Maqashid Syariah, Jakarta, Kencana, 2014.

Haq Hamka, Filsafat Ushul Fiqih, Ujung Pandang, Yayasan Al-Ahkam, 1998.

Harun Nasrun, Ushul Fiqih, Jakarta, Logos Wacana Ilmu, 1997.

Ibnu Mandzur, Lisaan al-'Arab, Kairo, Darul Ma'arif, t.t.

Khallaf Abd. Wahab, Kaidah-kaidah Hukum Islam, terjemah Nur Iskandar alBarsany, Jakarta, Rajawali, 1996.

Mas'ud Muhammad Khalid, Filsafat Hukum Islam dan Perubahan Sosial, terjemah Yudian W. Asmin, Surabaya, Al-Ikhlas, 1995.

Rusli Nasrun, Konsep Ijtihad as-Syaukani: Relevansinya bagi Pembaharuan Hukum Islam di Indonesia, Jakarta, Logos, 1999.

Syarifudin Amir, Ushul Fikih, Jakarta, Kencana, 2014.

Umam Khairu, Ushul Fiqih, Bandung, CV Pustaka Setia, 1998.

Zahrah Muhammad Abu, Ushul al-Figh, Beirut: Dar al-Fikr al-Islami, t.t. 